\title{
Laser Irradiated Nucleation Reduction Strategy of AMHP (Ammonium Magnesium Hydrogen Phosphate, In-Vivo Approach-1) Crystals in Gel Medium and its Characterization Studies
}

\author{
G. Kanchana ${ }^{1}$, P. Sundaramoorthi ${ }^{2 *}$, G.P. Jeyanthi ${ }^{1}$ \\ ${ }^{1}$ Department of Bio-chemistry, Avinashilingam Deemed University, Coimbatore, \\ TamilNadu, India. \\ 2*Department of Physics, A.A.Govt. Arts College, Namakkal - India-637001. \\ (sundara78@rediffmail.com)
}

\begin{abstract}
Kidney stone consists of various organic, inorganic and semi organic compounds. Mineral oxalate monohydrate and di-hydrate is the main inorganic constituent of kidney stones. However, mechanisms leading to the formation of mineral oxalate kidney stones are not clearly understood. In this field of study, there are several hypotheses including nucleation, crystal growth and or aggregation of formation of AOMH (Ammonium oxalate monohydrate) and AODH (Ammonium oxalate di-hydrate) crystals. The effect of some urinary species such as ammonium oxalates, calcium, citrate, proteins and trace elements were reported by the author. The kidney stone constituents are grown in the kidney environments, the silica gel medium (SMS) which provides the necessary growth simulation (in-vivo). In the artificial urinary stone growth process, identification of growth parameters with in the different chemical environment was carried out and reported for the urinary crystals such as CHP, SHP, BHP and MHP. In the present study, AMHP (Ammonium magnesium hydrogen phosphate) crystals are grown in three different growth faces to attain the total nucleation reduction. Extension of this research is that many characterization studies have been carried out and the results are reported.
\end{abstract}

Key words: Kidney stone, ammonium oxalate, monohydrate, di-hydrate, silica gel, urinary stone, ammonium magnesium hydrogen phosphate, nucleation reduction 


\section{INTRODUCTION}

Most kidney stones consist of a complex matrix with bio-minerals. The organic matrix has a composition that remains constant regardless of the type of crystals that make up the stone $[1,2]$. The urinary stone matrix accounts for approximately $3 \%$ of the weight of a calculus [3]. From the analysis, the matrix compound are soluble [4] and has been described as a homogeneous or heterogeneous material composed of organic, inorganic and semi organic compounds like protein, lipids, carbohydrates and cellular minerals etc. [5]. Proteins are the major constituents of stone matrix and the principle macromolecule in the urine [6]. Urinary proteins with the potential to adjust crystallization of mineral oxalates and calcium phosphate are Tamm-Horsfall protein, nepheromineralin, osteopontin, calprotectin, human serum albumin and urinary prothrombin fragment [5]. The renal tubular epithelial cells of the kidney chiefly produce most of the proteins. Other protein such as caprotectin, which is produced by granulocytes are commonly released at the sites of inflammation has also been of concern in stone formation. The bio-minerals contain hard minerals like $\mathrm{Ca}, \mathrm{Ba}, \mathrm{Sr}, \mathrm{Mg}$ and phosphates or its mixtures. The common and important constituents of all the stones are calcium. Normally calcium is found at concentrations of $8.9-10.1 \mathrm{mg} / \mathrm{ml}$ in the plasma [7]. Hypermineraluria is a biological syndrome defined as the execration of more than $0.1 \mathrm{mmol} / \mathrm{kg} / 24$ hours of major minerals in the urine. Hypermineraluria is the most common metabolic abnormality in patients with nephrolithiasis [8]. Hypermineraluria raises urine supersaturation with respect to the solid phase of mineral complex with phosphate thus enhancing the probability of self-nucleation and growth in to clinically significant stones.

Urinary minerals excretion is continuously influenced by the dietary intakes of calcium, sodium, protein, carbohydrates, alcohol, ammonium, trace element and potassium [9]. A mineral has been shown to bind to oxalate to form mineral oxalate monohydrate. Thus, mineral has been shown to affect the concentration of oxalate .In addition, oxalate is a major component of urinary stones and its urinary concentration plays an important role in stone formation. Even a small increase in urinary oxalate has a significant impact on mineral oxalate saturation. Although primary hyperoxaluria is relatively uncommon, patients with mineral oxalate stones have some degree of hyperoxaluria [10]. More amounts of oxalates are obtained from foods such as nuts, chocolate and dark green leafy vegetables [11]. The concentration of citrate in plasma ranges from 0.05-0.03 mmoles/liter and it exits as an alkaline citrate [12]. Citrate inhibits crystallization of mineral oxalate and mineral phosphate by several mechanisms. (a) It decreases urinary saturation of mineral salts by forming complex with minerals and reducing ionic minerals concentration [13]. (b) Citrate directly inhibits spontaneous precipitation of mineral oxalate [14], agglomeration of mineral oxalate [15], crystal growth of mineral phosphate [13] and heterogeneous nucleation of mineral oxalate by monosodium urate [16]. (c) Citrate converts glycoproteins to an active disaggregated state probably enhancing their inhibitor activity against the crystallization of calcium salts [17-18]. Due to the inhibitory role of citrate mentioned above, patients with hypocitraturia would be at a higher risk of renal stones. This fact indicates that hypocitraturia is an important factor for stone formation. 
The kinetic process of AOMH (Ammonium oxalate monohydrate) nucleation and crystal growth requires super saturation [19], which can be obtained by excretion of the reactants in the urine (Ammonium, calcium, trace element, oxalate and water). Few molecules are combined together to form clusters. In the early step, clusters do not show a high degree of internal ordering [20] The longer time they exist, however, their degree of ordering increases by replacing internal salvation bonds solid ion-ion bonds. Gradually, clusters become crystal embryos. Above a critical size, embryos will grow into stable nuclei and below the critical size, crystal embryos are too small and will reduce over all free energy by dissolving. The size of the nuclei is usually $100 \mathrm{~A}^{\circ}$ or less [21]. Once crystal nucleus has reached its critical size and super saturation ratio remains above one, over all free energy is decreased by adding new crystal components to the nucleus (self, spontaneous growth). This process is technically called as crystal growth.

\section{MATERIALS AND METHODS}

The silica gel also known as water glass was used in the present work as an intermediate growth medium. SMS (ARG-sodium meta silicate powder) was added to the double distilled water in the ratio of 1:1 and mixed well and kept undisturbed for few days to allow sedimentation. Then the clear top solution was filtered and stored in a light protected glass container which is known as a stock solution [22]. The gel densities of 1.03-1.06 grm/cc were used. Simple test tubes of $25 \mathrm{~mm}$ diameter and $150 \mathrm{~mm}$ length was used. The concentrations of orthophosphoric acid used in this experiment are $0.5 \mathrm{~N}, 1 \mathrm{~N}$ and $2 \mathrm{~N}$. The concentration of supernatant solution (ammonium chloride and $\mathrm{Mg}\left(\mathrm{NO}_{3}\right)_{2} 2 \mathrm{H}_{2} \mathrm{O}$ ) varies form $0.5: 0.5 \mathrm{M}$ to $2: 2 \mathrm{M}$ [23-24]. One of the reactants, orthophosphoric acid was mixed with in the gel solution. The gel solution was taken as one third of its volume of the test tubes and after the gel set, the supernatant solution was added slowly along the sides of the test tubes. The mixture diffuses through the gel medium which contains orthophorphoric acid.

The chemical reaction takes places which leads to the growth of $\mathrm{NH}_{4} \mathrm{MgHPO}_{4}$ crystal. The chemical reaction is

$\mathrm{NH}_{4}{ }^{+}+\mathrm{Mg}^{2+}+\mathrm{HPO}_{4}{ }^{2-}+2 \mathrm{H}_{2} \mathrm{O}=>\mathrm{NH}_{4} \mathrm{MgPO} 4.2 \mathrm{H}_{2} \mathrm{O} .+$ by products 
Table 1. Growth parameters of AMHP crystals (SDP).

\begin{tabular}{|c|c|c|c|c|c|c|c|}
\hline $\begin{array}{l}\text { SMS } \\
\text { gel } \\
\text { density } \\
\text { gm /cc }\end{array}$ & $\begin{array}{l}\text { Ortho } \\
\text { phosphoric } \\
\text { acid } \\
\text { concentrati } \\
\text { on }\end{array}$ & $\begin{array}{l}\mathrm{Gel+} \\
\mathrm{H}_{3} \mathrm{PO}_{4} \\
\mathrm{pH} \\
\text { value }\end{array}$ & $\begin{array}{ll}\text { Gel } & \text { setting } \\
\text { time } & \end{array}$ & $\begin{array}{l}\text { Supernatant } \\
\text { Concentration } \\
\text { Ammonium } \\
\text { chloride+ } \\
\mathrm{Mg} \quad\left(\mathrm{NO}_{3}\right) 2 . \\
2 \mathrm{H}_{2} \mathrm{O} \\
(\mathrm{M})\end{array}$ & $\begin{array}{l}\text { Nucleation } \\
\text { observed in } \\
\text { hours }\end{array}$ & $\begin{array}{l}\text { Growth } \\
\text { period } \\
\text { days }\end{array}$ & $\begin{array}{l}\text { Types of crystal } \\
\text { observed/ Harvested } \\
\text { crystal size. }\end{array}$ \\
\hline \multirow[b]{2}{*}{1.05} & $0.5 \mathrm{~N}$ & $\begin{array}{l}6.5 \\
6.9 \\
7.2\end{array}$ & $\begin{array}{l}24 \text { hours } \\
\text { 1hour } \\
34 \text { hours }\end{array}$ & $\begin{array}{c}2 . \\
\text {-do- } \\
\text {-do- }\end{array}$ & $\begin{array}{l}16 \\
\mathbf{2 0} \\
100\end{array}$ & 70 & \multirow{4}{*}{$\begin{array}{l}\text { Many poly } \\
\text { crystals, } \\
\text { Dendrite } \\
\text { crystals, } \\
\text { Liesegang rings } \\
\text { are observed }\end{array}$} \\
\hline & $1 \mathrm{~N}$ & $\begin{array}{l}6.5 \\
7.0 \\
7.5\end{array}$ & $\begin{array}{l}14 \text { hours } \\
\mathbf{1} \text { hour } \\
28 \text { hours }\end{array}$ & $\begin{array}{l}\text {-do- } \\
\text {-do- } \\
\text {-do- }\end{array}$ & $\begin{array}{l}10 \\
06 \\
64\end{array}$ & 80 & \\
\hline \multirow[b]{2}{*}{1.04} & $0.5 \mathrm{~N}$ & $\begin{array}{l}6.4 \\
6.9 \\
7.3\end{array}$ & $\begin{array}{l}34 \text { hours } \\
\text { 1hour } \\
48 \text { hours }\end{array}$ & $\begin{array}{l}\text {-do- } \\
- \text { do- } \\
\text {-do- }\end{array}$ & $\begin{array}{l}\mathbf{1 0} \\
\mathbf{1 2} \\
38\end{array}$ & 60 & \\
\hline & $1 N$ & $\begin{array}{l}6.5 \\
6.8 \\
7.3\end{array}$ & $\begin{array}{l}16 \text { hours } \\
\mathbf{1} \text { hour } \\
24 \text { hours }\end{array}$ & $\begin{array}{l}\text {-do- } \\
\text {-do- } \\
- \text { do- }\end{array}$ & $\begin{array}{l}24 \\
\mathbf{1 0} \\
64\end{array}$ & 65 & \\
\hline
\end{tabular}



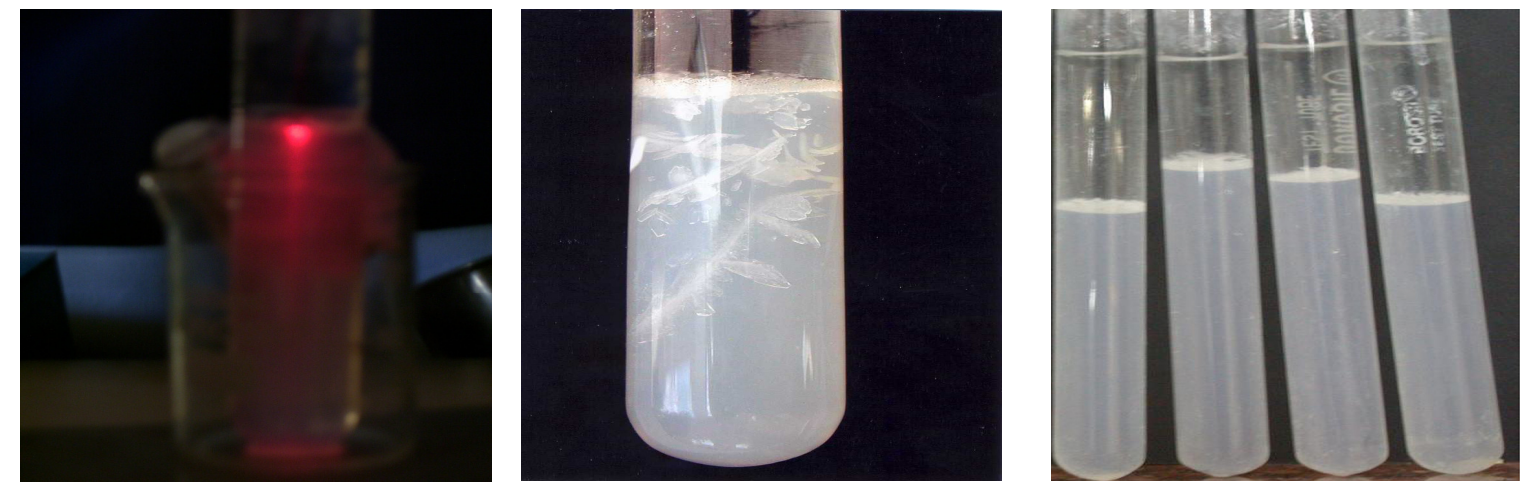

Fig.1 (a) Laser medium

Fig (b) Laboratory medium

Fig.1 (c) Sunlight medium

Fig.1. Growth of AMHP crystals in different environments (SDP)

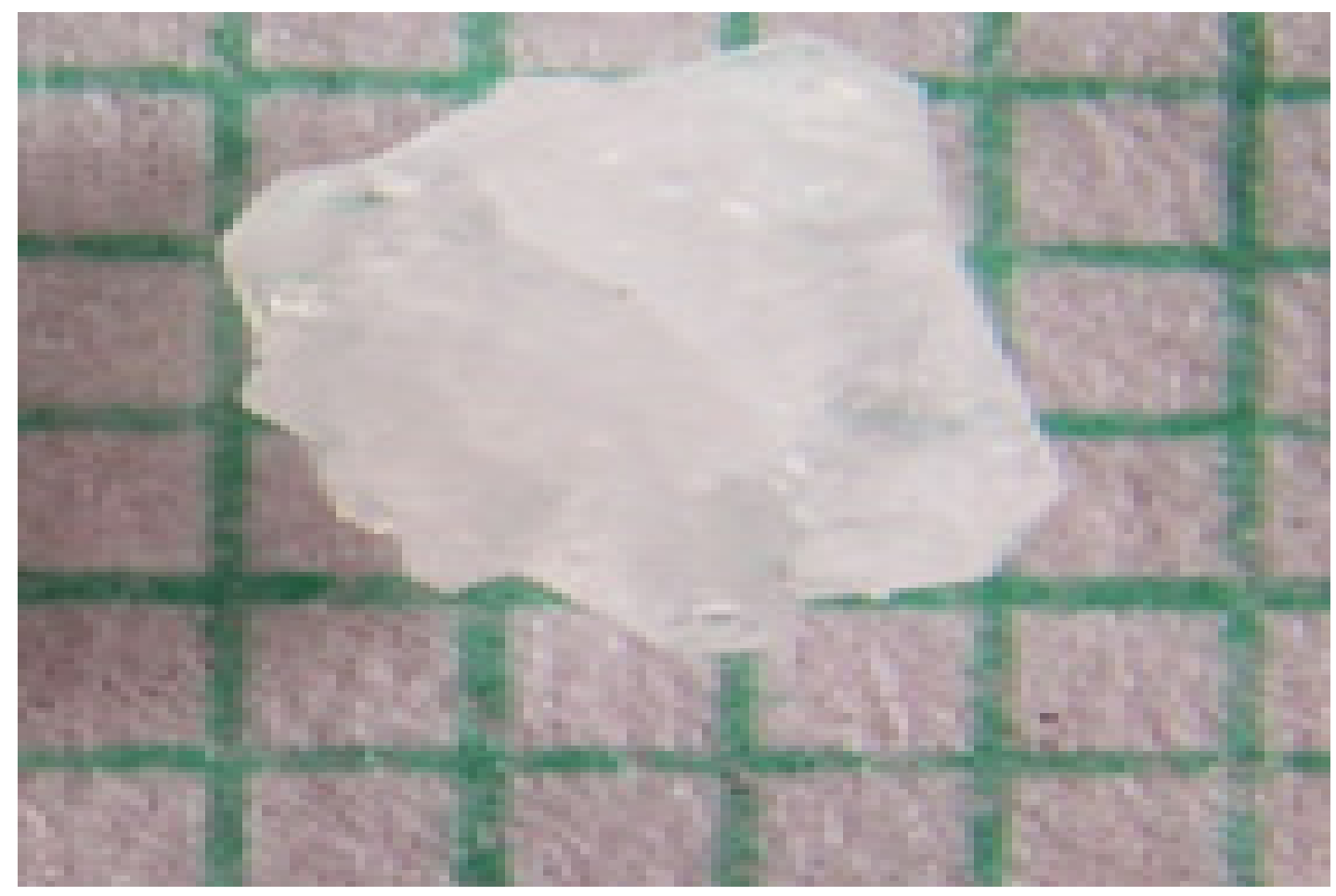

Fig.2. Harvested AMHP crystal in SDP. 


\section{RESULT AND DISCUSSION}

AMHP crystals are grown in three different growth faces by applying various growth parameters. Table-1 gives the growth parameters of AMHP crystals and the bold letters shows the optimum growth parameters. Among them, the laser exposed growth medium shows better nucleation reduction and no crystals were formed because of the inability to attain super saturation. In sunlight exposed medium, partial nucleation was observed since exposure of sunlight to the growth medium was only in day time that is 8 hours per day and the growth period was 3 months.

\subsection{FTIR Spectral Analysis of AMHP Crystal}

AMHP-FTIR spectrum was recorded using SHIMADZU FTIR-435 instrument. The FTIR spectrometer have $\mathrm{KBr}$ pellets sample holder and $\mathrm{KBr}$ detector. The $\mathrm{KBr}$ pellet samples were used and the absorption frequencies range from $400 \mathrm{~cm}^{-1}$ to $4000 \mathrm{~cm}^{-1}$. Fig-3 shows the FTIR spectrum of AMHP crystal. The spectrum was interpreted with the earlier reported values [25-27]. The absorption bonds, absorption frequencies and percentage of transmittance are compared with the reported values and match the major constituents present in the AMHP crystals. In this computation acid phosphate group frequency was $566.27 \mathrm{~cm}^{-1}, \mathrm{PO}_{4}$ group frequency was $1117.2 \mathrm{~cm}^{-1}$ then $\mathrm{NH}$ in plane bending frequency was $1237 \mathrm{~cm}^{-1}$ and also water molecule asymmetric, symmetric stretching was $3272 \mathrm{~cm}^{-1}, 1659 \mathrm{~cm}^{-1}$.



Fig.3. FTIR spectrum of AMHP crystals 


\subsection{Thermo Gravimetric (TGA and DTA) Analysis of AMHP Crystal}

The TGA and DTA of AMHP crystal was carried out by STA 11500-PLTS instrument. AMHP crystal of $2.439 \mathrm{mg}$ sample was taken for the TGA process. The TGA was started from room temperature to $1000^{\circ} \mathrm{C}$ by heating at a constant rate. Fig- 4 shows the TGA\&DTA graph of AMHP crystal. The percentage of weight loss of the AMHP sample at $77.2^{0} \mathrm{C}$ was $0.5 \%$ alone due to moistures, further at $133^{\circ} \mathrm{C}$ weight loss was $25 \%$ due to water molecule. Then above $364^{\circ} \mathrm{C}$ to still end $\left(900^{\circ} \mathrm{C}\right)$ of the analysis the weight loss are $40.5 \%$ due to hydroxyl and ammonium compounds.

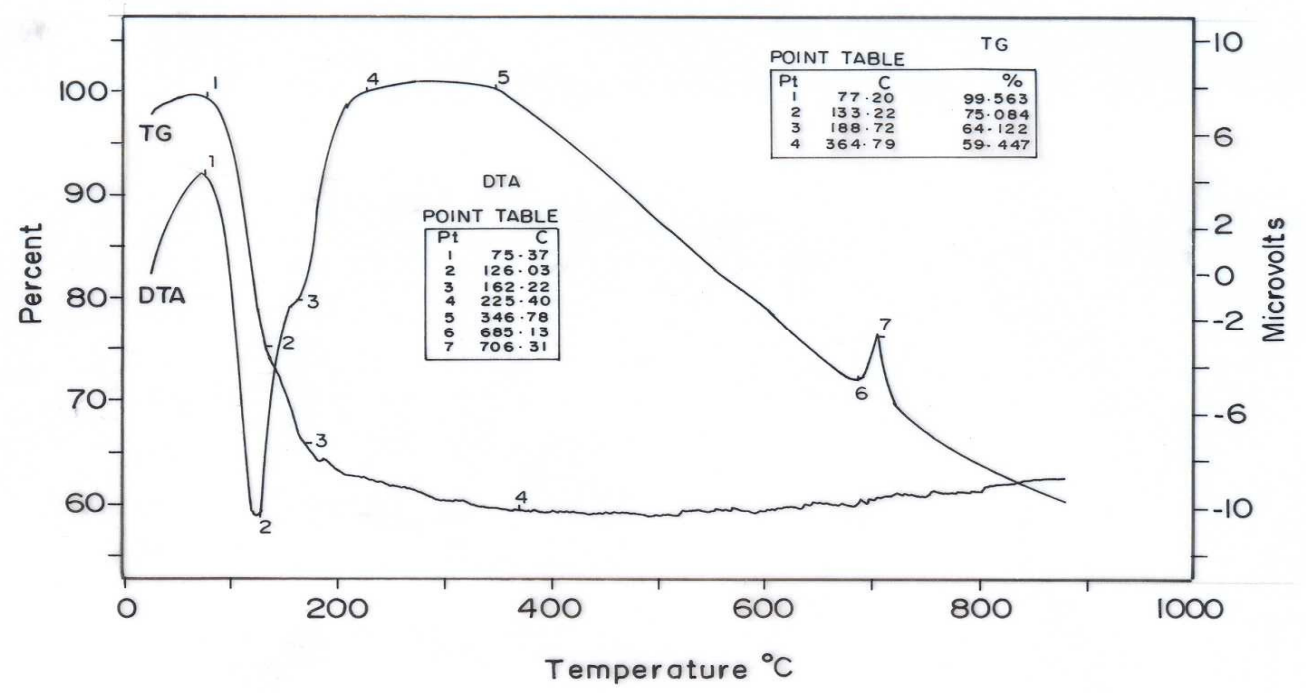

Fig 4 Thermo gravimetric (TGA and DTA) analysis of AMHP cystals.

\subsection{Etching Study of AMHP Crystal}

A well-grown AMHP crystal was immersed in $\mathrm{HCl}$ solution at a desired concentration. The dissolution of AMHP crystal depends upon on the etchant concentration, temperature, crystal morphology, etching time etc. The etch pits are photographed. Fig.5 shows the etch pits of AMHP crystal [28-31]. The etch pit patterns observed are spirals, dendrites, allies and straights.

\subsection{Scanning Electron Microscopic Study of AMHP Crystal}

A well-grown AMHP single crystal was selected for the investigation of surface morphology of the grown crystal by using SEM. The SEM photograph was obtained in the version S-300-I instrument. The sample named as VCA-600 was kept in lobe middle; the data size was $640 \mu \mathrm{m}$ x $480 \mu \mathrm{m}$. The minor and major magnification of SEM was about 250 times. SEM acceleration voltage was 25000 volts and the sample was kept in highly vacuum state. 
$18200-\mu \mathrm{m}$ work distance was maintained and monochromatic color modes were employed. Fig.6. shows the SEM pattern of AMHP crystal [32-35].



Fig 5 Shows the etch pit pattern of AMHP crystals



Fig.6 SEM photo of AMHP crystal. 


\subsection{X-ray Powder Diffraction}

The XRPD results revealed that the grown crystal was in single phase of AMHP crystal. The XRPD pattern and diffraction indices of the crystal are shown in Fig.7. Terror programmer according to the values of $2 \theta$ in XRPD calculates the cell parameters. The unit cell parameters of AMHP crystals are $a=7.0672 \AA, b=18.4739 \AA, c=23.7069 \AA$ and $\alpha=\beta=\gamma=90^{\circ}$ the crystal system is Orthorhombic. The volume of the AMHP unit cell is $3092.87(\AA)^{3}$

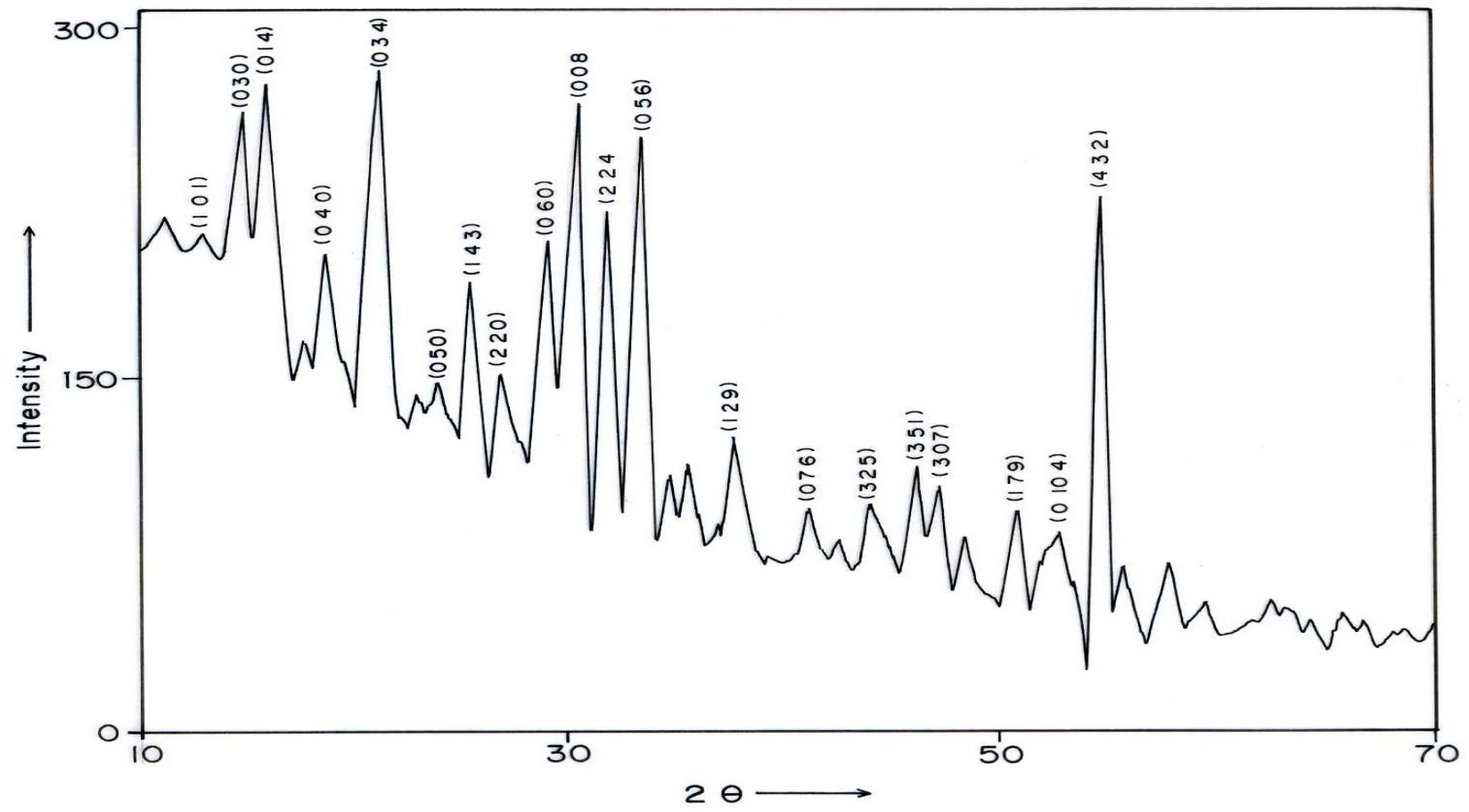

Fig 7 Powder XRD pattern of AMHP crystal

\section{CONCLUSION}

AMHP (Ammonium magnesium hydrogen phosphate) crystals were grown at room temperature and exposure to sunlight and laser medium. It was found that AMHP crystal nucleation rate have been reduced more in the laser exposed medium than the sunlightexposed medium which is due to variation of super saturations. FTIR-spectrum recorded the functional group frequencies of AMHP crystal constituents. These results are compared with the reported values. Chemical etchings are carried at room temperature which revealed the grown crystal defects. SEM analyses are also done and it reveals the surface morphology of AMHP crystal. The decomposition temperature and percentage of weight loss of the grown crystal are recorded by TGA and DTA analysis. XRPD data gives the AMHP grown crystal cell parameters and its structure. 


\section{REFERENCES}

[1] S.R.Khan, P.O.Whalen and P.A.Glenton, J.Cryst.Growth 134 (1993) 211.

[2] W.H.Boyce, Am.J.Med.45(5) (1968) 673.

[3] H.G.Tiselius, Clin.Chim.Acta.122 (1982) 409.

[4] R.W.Marshall and W.G.Robertson, Clin.Chim.Acta.72 (1976) 253.

[5] S.R.Khan, Urol.Int 59 (1997) 59.

[6] R.L.Ryall, A.M.F.Stapleton, in calcium oxalate in Biological system, Edi.S.R.Khan (CRC press) (1995).

[7] C.G.Duarte and F.G.Knox, in text book of renal pathophysiology (Harper and Row (1978).

[8] F.L.Coe, J.H.Parks and J.R.Asplin, N.Engl.J.Med. 327 (1992) 1141.

[9] Maurice Audran and Erick Legrand, Joint Bone spine 67(6) (2000) 509.

[10] Y.Ogawa, T.miyazato and T.Hataano,World j.Surgery 24(10) (2000) 1154.

[11] D.S.Goldfarb and F.L.Coe, Am.Fam.Physicican.60(8) (2000) 2269.

[12] D.P.Simpson, Am.J.Physiol.224(3)F (1983) 223.

[13] J.L.Mayer and L.Hsmith, Invest.Urol 13 (1975) 36.

[14] M.J.Nicar, K.Hill and C.Y.C.Pack, J.Bone. Miner.Res.2(3) (1987) 215.

[15] D.J.Kok, S.E.Papapoulus and O.L.M.Bijvoet,Lancet 41 (1986) 1056.

[16] C.Y.C. Pak and Paterson, Arch.Intern.Med.146 (1986) 863.

[17] B.Hess, Miner.Electr.Metab 20 (1996) 393.

[18] C.Y.C.Pak, Hypocitraturia; a critical review and furture direction,from $8^{\text {th }}$ European symposium on Urolithiasis-Parma,Italy,June 9-12 (1999).

[19] A.Mersmann,Crystallization technology,Hand book, $2^{\text {nd }}$ Edi. Marcel Dekker,Inc.(2000).

[20] V.A.Garten and R.B.Head,Phil.Mag.14 (1966) 1243.

[21] D.J.Kok, The role of crystallization process in mineral oxlates urolithasis, Ph.D thesis, Univerasity of Leiden (1991).

[22] H.K. Henisch, J Electro Chemical. Soc., 112 (1965) 627.

[23] A.E.Alexander and P.Honson, Colloid Science, Clarendon Press, Oxford, (1949).

[24] W.Eitel, In:Physical chemistry of Silicate University of Chicago Press (1954).

[25] Yean. Chin Dasai, J. Urol. Vol 86, (1961) 838-854.

[26] C.M. Corns, Ann. Clin. Bio-Cherm, Vol 20, (1983) 20-35.

[27] A.Hesse , D. Bach,. Stone analysis by IR spectroscopy, Clinical and laboratory Aspects, Edi.Alan Rose, University Park Press, Baltimore, PP.87-105, 1982.

[28] J.J.Gilman, J.Johnsion and G.W.Sears, J.Appl.Physics, 29(1958) 749.

[29] J.J. Gilman, J.Appl.Physics, 27 (1956) 1018.

[30] J.C.Fisher, in: Dissolutions and Mechanical Properties of Crystals, John Wiley and sons, NewYork (1957).

[31] J.B. New Kirk, in: Director observation of Imperfection in crystals, Inter science Publisers, New York (1962).

[32]. K. Taukamot, J. Cryst. Growth, 61,(1983)99.

[33]. H.C.Gates, Thirty years of progress in Surface Science, in: Crystal growth and characterization,(Edi),North Holland, 1975. 
[34]. H.Bethage etal, Electron Microscopy in Solid State Physics, Elsevier, Amsterdom, 1987 [35] N. Albon etal, in: Growth and Perfection of Crystals, Wiley, New York, P.44 1958. 